\title{
A simulation approach: Miscible carbon dioxide injection in a carbonate reservoir
}

\author{
Ehsan Heidaryan ${ }^{1 *}$, Jamshid Moghadasi ${ }^{2}$ and Marylena Garcia Quijada ${ }^{3}$ \\ ${ }^{1}$ Faculty of Energy, Kermanshah University of Technology, Kermanshah, Iran \\ ${ }^{2}$ Petroleum Engineering Department, Petroleum University of Technology, Ahwaz, Iran \\ ${ }^{3}$ Texas A\&M University, College Station, Texas, USA
}

(C) China University of Petroleum (Beijing) and Springer-Verlag Berlin Heidelberg 2010

\begin{abstract}
The purpose of this study is to optimize the existing carbon dioxide $\left(\mathrm{CO}_{2}\right)$ flood in deep dolomite formations by improving oil sweep efficiency of miscible $\mathrm{CO}_{2}$ floods and enhancing the conformance control. A full compositional simulation model using a detailed geologic characterization was built to optimize the injection pattern. The model is a quarter of an inverted nine-spot and covers 20 acres of field formation. Geologic description was used to construct the simulation grids. The simulation layers represent actual flow units and resemble the large variation of reservoir properties. History match was performed to validate the model. Several sensitivity runs were made to improve the $\mathrm{CO}_{2}$ sweep efficiency and increase the oil recovery. Finally, the optimum $\mathrm{CO}_{2}$ injection rate for dolomite formations was determined approximately. Simulation results also indicate that a water-alternating-gas (WAG) ratio of $1: 1$ along with an ultimate $\mathrm{CO}_{2}$ slug of $100 \%$ hydrocarbon pore volume (HCPV) will allow an incremental oil recovery of $18 \%$. The additional recovery increases to $34 \%$ if a polymer is injected as a conformance control agent during the course of the WAG process at a ratio of 1:1. According to the results, a pattern reconfiguration change from the nine spot to staggered line drive would represent an incremental oil recovery of $26 \%$.
\end{abstract}

Key words: Miscible injection, carbon dioxide, dolomite formation, water-alternating-gas

\section{Introduction}

Carbon dioxide $\left(\mathrm{CO}_{2}\right)$ flooding processes can be classified as immiscible and/or miscible. Recovery mechanisms in miscible flooding processes involve reduction in oil viscosity, oil swelling, and solution-gas drive. In general, $\mathrm{CO}_{2}$ is very soluble in crude oil at reservoir pressures; therefore, it swells the oil and reduces oil viscosity (Martin and Taber, 1992). Miscibility between $\mathrm{CO}_{2}$ and crude is achieved through a multiple-contact miscibility process, which starts with densephase $\mathrm{CO}_{2}$ and hydrocarbon liquid. The $\mathrm{CO}_{2}$ first condenses into the oil, making it lighter and often driving methane out ahead of the oil bank. The lighter components of the oil then vaporize into the $\mathrm{CO}_{2}$-rich phase, making it denser, more like the oil, and thus more easily soluble in the oil. Mass transfer continues between the $\mathrm{CO}_{2}$ and the oil until the two mixtures become indistinguishable in terms of fluid properties (Jarrel et al, 2002).

Because of this mechanism, good recovery may occur at pressures high enough to achieve miscibility. In general, the high pressures are required to compress $\mathrm{CO}_{2}$ to a density at which it becomes a good solvent for the lighter hydrocarbons

*Corresponding author. email: heidaryan@engineer.com

Received March 27, 2009 in the crude oil. This pressure is known as minimum miscibility pressure (MMP), that is the minimum pressure at which miscibility between $\mathrm{CO}_{2}$ and crude can occur (Martin and Taber, 1992). This pressure is usually determined experimentally. The water-alternating-gas (WAG) process consists of the injection of water and gas as alternate slugs by cycles or simultaneously (SWAG), with the objective of improving the sweep efficiency of water flooding and miscible or immiscible gas-flood projects by reducing the impact of viscous fingering. A schematic of the WAG process is shown in the literature (Caudle and Dyes, 1959). During a WAG process, the combination of higher microscopic displacement efficiency of gas with better macroscopic sweep efficiency of water helps significantly increase the incremental production over a plain water flood. A wide variety of gases have been employed for a wide range of reservoir characteristics in the miscible mode; however, $\mathrm{CO}_{2}$ and hydrocarbon gases represent approximately $90 \%$ of the injected gases (Jarrel et al, 2002).

\section{Reservoir performance}

Cores analyses have revealed that the "main pay" interval presents three rock types: a pelletal dolomite packstone with interparticle and intercrystal porosity (pelletal packstone); a fossiliferous dolomite wackestone with moldic porosity 
(moldic wackestone); and a fossiliferous dolomite packstone with moldic and interparticle porosity (moldic packstone). The pelletal packstone rocks occur both as homogeneous units and in burrows and irregular patches in the wackestones. They have excellent reservoir rock properties; permeability can be as high as $152 \mathrm{mD}$ and interparticle porosity is up to $24.3 \%$. In the wackestone rocks, molds and vugs are the dominant pore types, ranging in size up to $6 \mathrm{~mm}$. Within the rock, molds are not in contact with other; core observation has revealed that the molds are isolated in the rock by a relatively tight matrix. This isolated moldic porosity negatively affects the reservoir properties of the rock. Permeability is less than $1 \mathrm{mD}$, even though moldic porosity may range as high as $10 \%$ (Mathis and Sears, 1984). Summary of reservoir data are given in Table 1. In preparation for the $\mathrm{CO}_{2}$ flood, the random waterflood pattern was converted into a nine-spot pattern.

Table 1 Summary of reservoir data

\begin{tabular}{|c|c|}
\hline Reservoir characteristics & Values \\
\hline Producing area, acres & 25505 \\
\hline Formation & Dolomite \\
\hline Average depth, $\mathrm{ft}$ & 5200 \\
\hline Gas-oil contact, $\mathrm{ft}$ & 1325 \\
\hline Average permeability, $\mathrm{mD}$ & 5 \\
\hline Average porosity & 0.12 \\
\hline Average net oil pay thickness, $\mathrm{ft}$ & \\
\hline Oil gravity, degrees API & \\
\hline Reservoir temperature, ${ }^{\circ} \mathrm{F}$ & \\
\hline Primary production mechanism & Solution-gas drive \\
\hline Secondary production mechanism & Waterflood \\
\hline Tertiary production mechanism & $\mathrm{O}_{2}$ miscible \\
\hline Original reservoir pressure & 1805 \\
\hline Bubble point pressure, & 1805 \\
\hline Average pressure at start of secondary recovery, psia & $\pm 800 / \pm 1100$ \\
\hline Target reservoir pressure for $\mathrm{CO}_{2}$, psia & 2200 \\
\hline Initial formation volume factor (FVF), bbl/STB & 1.312 \\
\hline Solution gas-oil ratio at original pressure, bbl/STB & 420 \\
\hline $\begin{array}{c}\text { Solution gas-oil ratio at start of secondary recovery } \\
\text { original pressure, } \mathrm{scf} / \mathrm{bbl}\end{array}$ & 1060 \\
\hline Oil viscosity at $60^{\circ} \mathrm{F}$ and $1100 \mathrm{psia}, \mathrm{cP}$ & 1.18 \\
\hline Minimum miscibility pressure, psia & 1300 \\
\hline
\end{tabular}

Oil production response was observed soon after injection began and the oil cut rose from below $14 \%$ to $31 \%$. In Fig. 1 $\mathrm{CO}_{2}$ response can be clearly seen on a plot of oil cut versus cumulative production. The WAG flood in the WAG area was started with a constant 1:1 gas/water ratio (1\% hydrocarbon pore volume (HCPV) of $\mathrm{CO}_{2}$ and $1 \% \mathrm{HCPV}$ of water). The original injection schedule involved injecting alternating 6-month slugs of $\mathrm{CO}_{2}$ and water until a $40 \%$ HCPV slug of $\mathrm{CO}_{2}$ had been injected.

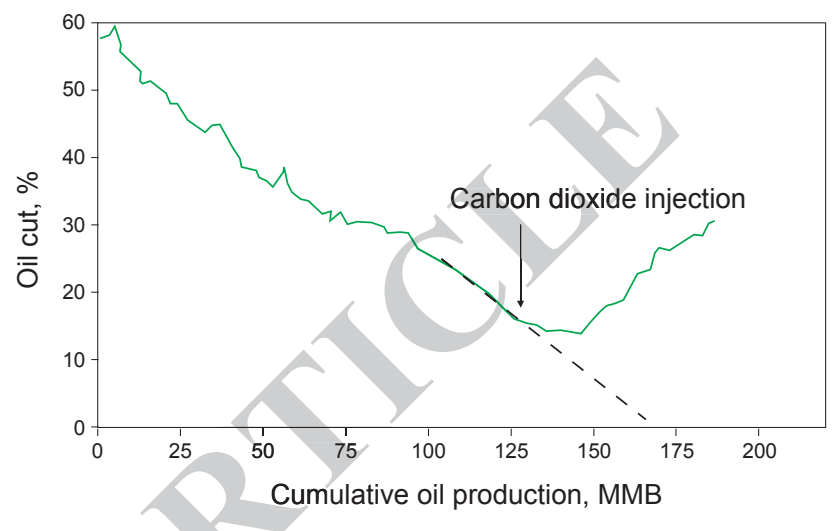

Fig. 1 Oil cut versus cumulative oil production during continuous $\mathrm{CO}_{2}$ flood

\section{Parameters modeling}

The reservoir oil is saturated black oil with a stock tank gravity of $33^{\circ}$ API and an initial gas-oil ratio (GOR) of 660 scf/STB. Initial reservoir pressure and bubble point pressure are $1,805 \mathrm{psia}$ at a reference depth of $5,000 \mathrm{ft}$ and $105^{\circ} \mathrm{F}$. The $\mathrm{CO}_{2}$ minimum miscibility pressure $(1,300$ psia) was determined experimentally. Reservoir fluid compositions are available in Table 2. The tuning of the equation of states (EOS) in this work followed the methodology suggested by Khan et al (1992) to characterize $\mathrm{CO}_{2}$ oil mixtures. The P-R EOS (Peng and Robinson, 1976) was chosen as the EOS model because it has been found adequate for low-temperature $\mathrm{CO}_{2}$ /oil mixtures (Khan et al, 1992). The viscosity model considered to match the oil viscosity of the reservoir fluid was the Lohrenz-Bray-Clark (LBC) model (Lohrenz et al, 1964) which is a predictive model for gas or liquid viscosity. Detailed PVT experiments are listed in Table 3; and the related preliminary matches by the basic EOS.

The maximum oil relative permeability is $65 \%$ at $15 \%$ connate water saturation $\left(S_{\mathrm{wc}}=15 \%\right)$. At $60 \%$ water saturation $\left(S_{\mathrm{wc}}=60 \%\right)$, the oil relative permeability is zero. As water is injected, the water relative permeability increases, reaching a maximum value of $50 \%$ at $60 \%$ water saturation.

Table 2 Reservoir fluid composition in mole fractions

\begin{tabular}{cccccccccccccc}
\hline Component & $\mathrm{CO}_{2}$ & $\mathrm{~N}_{2}$ & $\mathrm{C}_{1}$ & $\mathrm{C}_{2}$ & $\mathrm{C}_{3}$ & $i-\mathrm{C}_{4}$ & $n-\mathrm{C}_{4}$ & $i-\mathrm{C}_{5}$ & $n-\mathrm{C}_{5}$ & $\mathrm{C}_{6}$ & $\mathrm{C}_{7+}$ \\
\hline Mole fraction & 0.0297 & 0.0040 & 0.0861 & 0.0739 & 0.0764 & 0.0095 & 0.0627 & 0.0159 & 0.0384 & 0.0406 & 0.5628 \\
\hline
\end{tabular}


Table 3 PVT results for current reservoir fluid

\begin{tabular}{ccccccccc}
\hline Component & $M_{\mathrm{w}}$ & $\begin{array}{c}P_{\mathrm{c}} \\
\mathrm{psia}\end{array}$ & $\begin{array}{c}T_{\mathrm{c}} \\
{ }^{\circ} \mathrm{R}\end{array}$ & Omega A & Omega B & Acentric factor & $\begin{array}{c}V_{\mathrm{c}} \\
\mathrm{cft}\end{array}$ & $Z_{\mathrm{c}}$ \\
\hline $\mathrm{CO}_{2}$ & 44.01 & 1056.6 & 548.46 & 0.4572 & 0.0778 & 0.2250 & 1.5057 & 0.2741 \\
$\mathrm{C}_{1}+\mathrm{N}_{2}$ & 16.14 & 651.63 & 342.12 & 0.4572 & 0.0778 & 0.0132 & 1.5688 & 0.2847 \\
$\mathrm{C}_{2}+\mathrm{C}_{3}$ & 37.42 & 646.69 & 610.46 & 0.4572 & 0.0778 & 0.1268 & 2.8070 & 0.2834 \\
$i-\mathrm{C}_{4}+n-\mathrm{C}_{4}$ & 58.12 & 527.79 & 753.72 & 0.4572 & 0.0778 & 0.1949 & 4.1332 & 0.2772 \\
$\mathrm{C}_{5}-\mathrm{C}_{6}$ & 80.50 & 387.02 & 822.01 & 0.4572 & 0.0778 & 0.1584 & 6.1030 & 0.2779 \\
$\mathrm{C}_{7+}$ & 220.00 & 262.79 & 1283.4 & 0.4572 & 0.0778 & 0.7040 & 11.5740 & 0.2332 \\
\hline
\end{tabular}

\section{Reservoir simulation parameters}

The reservoir model for the simulation study is a quarter of an 80 acre inverted nine spot pattern. The model covers 20 acres and contains 3 production wells and one injection well. Both production and injection wells are vertical and completed in all the layers of the simulation model. There are 4,800 cells in the model with $49.12 \mathrm{ft}$ on the sides. Areal gridding sensitivities provided the grid size needed for the model. The $20 \times 20$ grid design provided satisfactory results when compared with more finely gridded models. Twelve different layers described in the geologic model represent the actual geology. Simulation layers were constructed to represent the actual reservoir zonation and resemble actual flow units. Layer thicknesses were determined from marker tops in well logs. Average porosity for each layer was calculated from sonic logs between markers. The reservoir model was initiated at a uniform pressure of 1,805 psia and constant temperature of $105^{\circ} \mathrm{F}$. The initial water saturation from the relative permeability curve was $15 \%$. Initial oil saturation within the grid blocks was $85 \%$. The geologic model provided an estimate of OOIP of $2.29 \mathrm{MMbbl}$ at initialization. The related information is ayailable in Table 4.

Table $\mathbf{4}$ Net pay, porosity and permeability in the simulation model

\begin{tabular}{|c|c|c|c|}
\hline Layer & $\begin{array}{c}\text { Net } p \\
f t\end{array}$ & Porosity & $\begin{array}{c}\text { Permeability } K_{x} \\
\mathrm{mD}\end{array}$ \\
\hline $\mathrm{F}_{4}$ & 10.50 & 0.102 & 0.767 \\
\hline $\mathrm{F}_{4} / \mathrm{F}_{5}$ & 37.50 & 0.114 & 1.212 \\
\hline $\mathrm{M}_{1}$ & 19.00 & 0.125 & 6.002 \\
\hline $\mathrm{M}_{1}$ & 9.50 & 0.177 & 23.00 \\
\hline $\mathrm{M}_{1}$ & 6.00 & 0.151 & 12.43 \\
\hline $\mathrm{M}_{2}$ & 20.50 & 0.106 & 3.352 \\
\hline $\mathrm{M}_{2} / \mathrm{M}_{3}$ & 37.50 & 0.090 & 1.765 \\
\hline $\mathrm{M}_{3}$ & 12.50 & 0.142 & 10.82 \\
\hline $\mathrm{M}_{3}$ & 46.00 & 0.099 & 2.562 \\
\hline $\mathrm{M}_{4}$ & 15.00 & 0.067 & 0.630 \\
\hline $\mathrm{M}_{4}$ & 28.50 & 0.105 & 2.707 \\
\hline $\mathrm{M}_{4} / \mathrm{M}_{5}$ & 50.00 & 0.107 & 2.880 \\
\hline
\end{tabular}

Usually the only way to test the validity of a model is to simulate past performance of the reservoir and compare the simulation results with historical performance. During the waterflood period, water cut match is fairly good at early times. However, the overall water production matches very well. A reasonable match of the gas production was also obtained. Figs. 2-4 contrast historical and simulated gas and water production during the history match period.

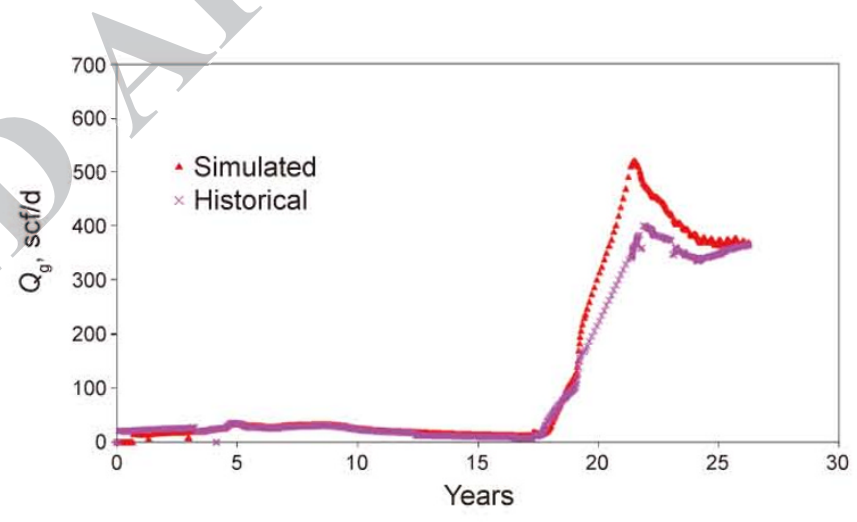

Fig. 2 Gas production history match

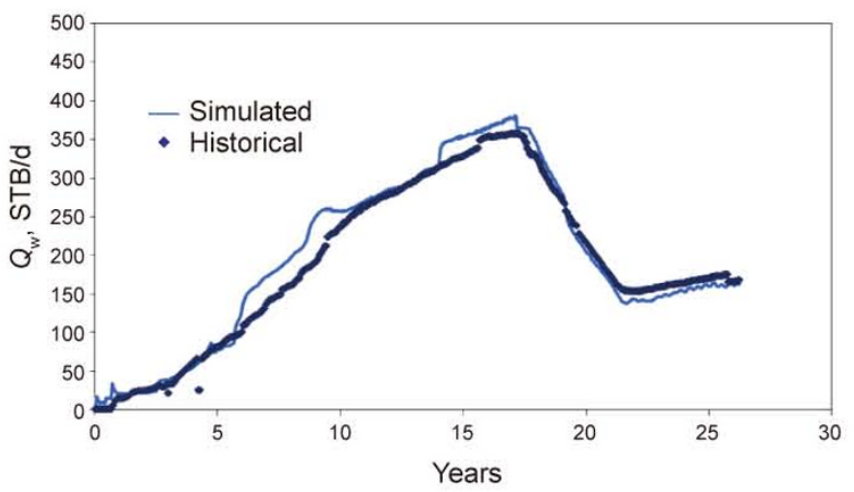

Fig. 3 Water production history match

At the end of the period, layers F4 through M5, which initially contained 2.29 MMSTBO, had produced 893,862 STB or $39 \%$ of the OOIP, thus leaving a remaining volume in place of 1.39 MMSTBO. The average remaining oil saturation at the end of the history match was $45 \%$. The transitions of the distribution of the oil saturation during the history match 


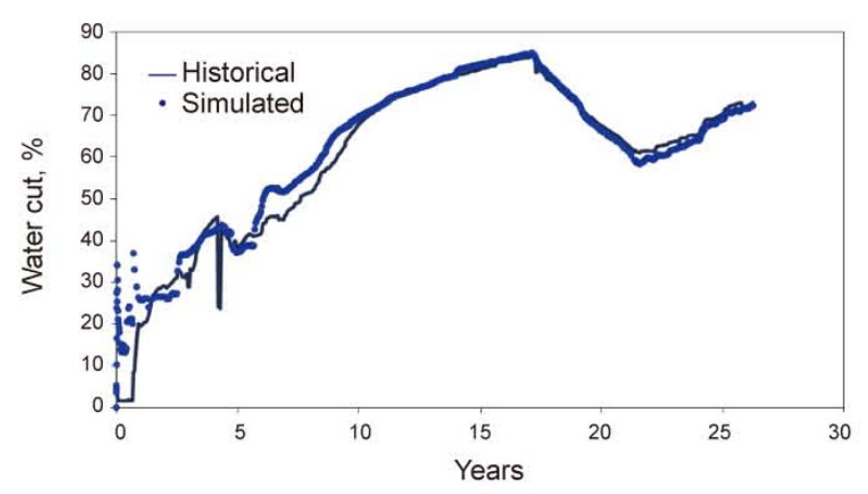

Fig. 4 Water cut history match period are shown in Fig. 5. Similarly, cross-sectional view of oil saturation distribution in the model is shown in Fig. 6 throughout the history match.

\section{Optimization of miscible WAG process}

To investigate the effect of the injection rate on the WAG process four sensitivities were performed at a WAG ratio of $1: 1$ using constant rates of 100, 200, 300 and $500 \mathrm{bbl} / \mathrm{d}$ (233.5, 467, 762 and $1167 \mathrm{Mscf} / \mathrm{d}$ respectively) of $\mathrm{CO}_{2}$. Half cycle of $3 \% \mathrm{HCPV}$ of $\mathrm{CO}_{2}$ and $3 \% \mathrm{HCPV}$ of water were injected until a fixed total $\mathrm{CO}_{2}$ slug of $30 \% \mathrm{HCPV}$ was reached. As it is indicated in Fig. 7, the optimum injection rate for a 1:1 WAG ratio is approximately $300 \mathrm{bbl} / \mathrm{d}(762 \mathrm{Mscf} / \mathrm{d})$.

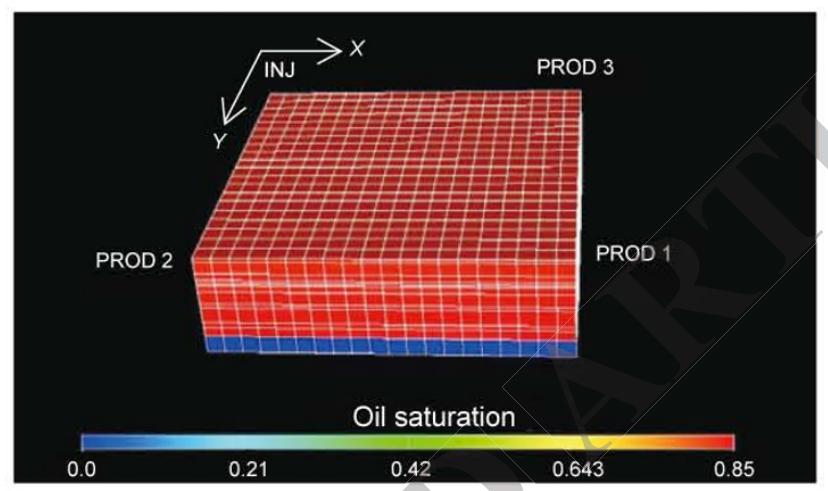

(a) Year \#0

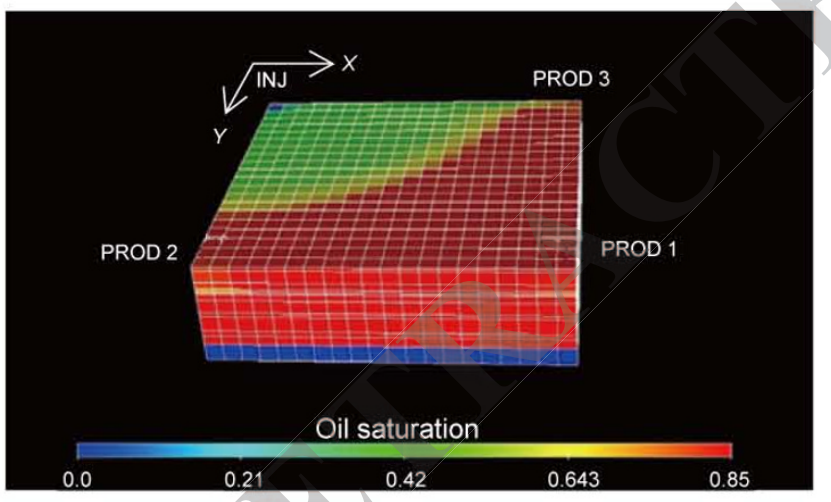

(b) Year \#6

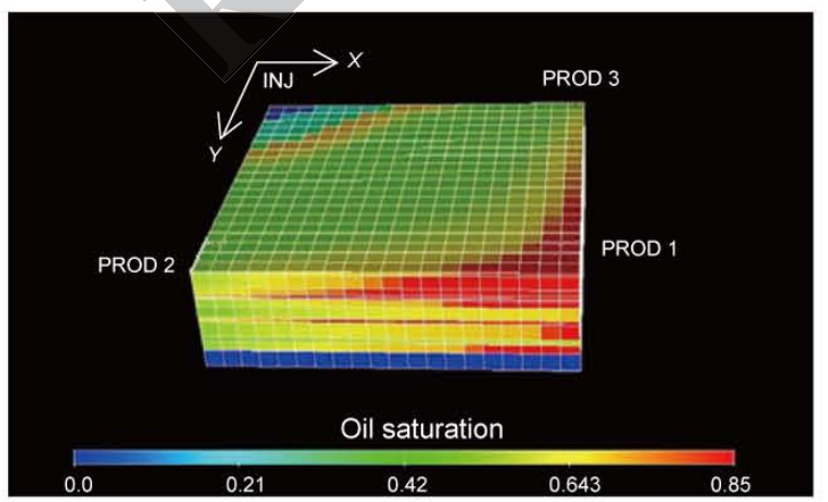

(d) Year \#18

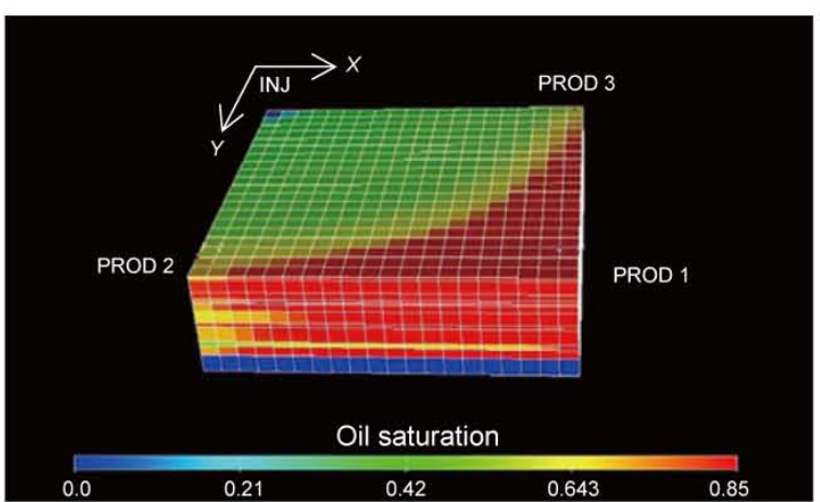

(c) Year \#12

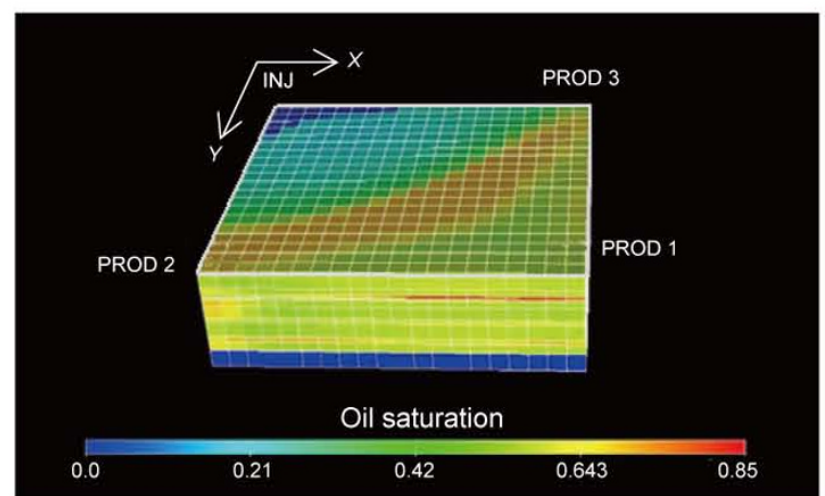

(e) Year \#24

Fig. 5 Perspective view of the oil saturation distribution 


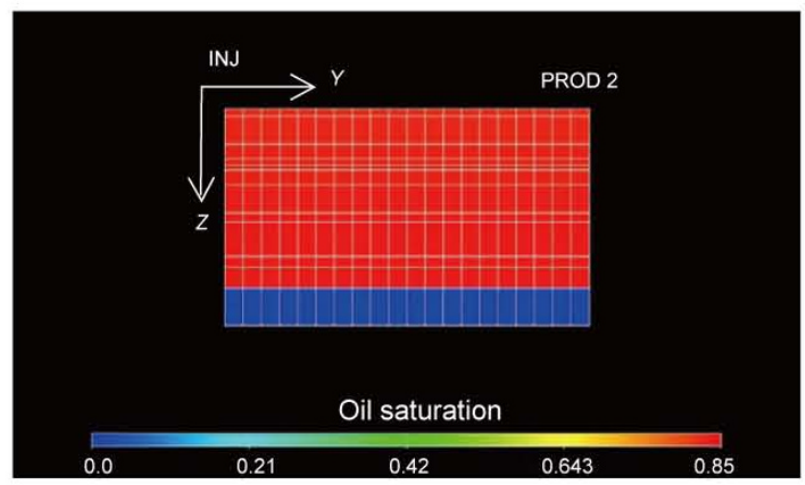

(a) Year \#0

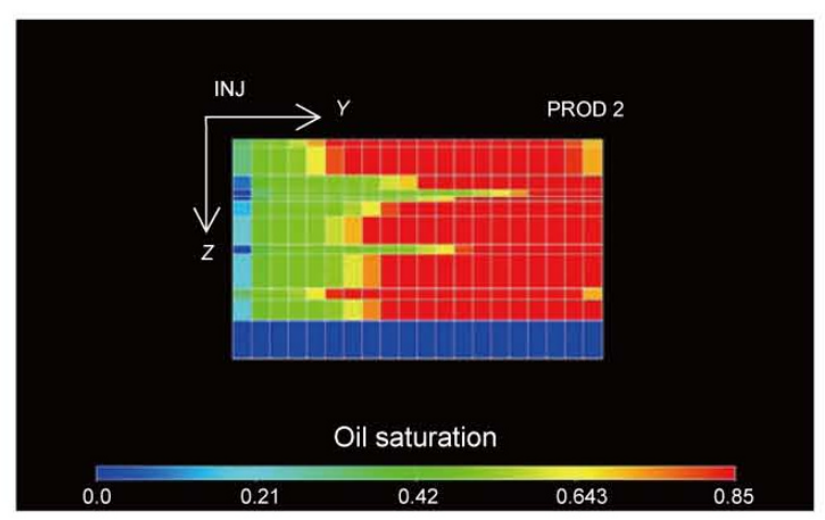

(b) Year \#6

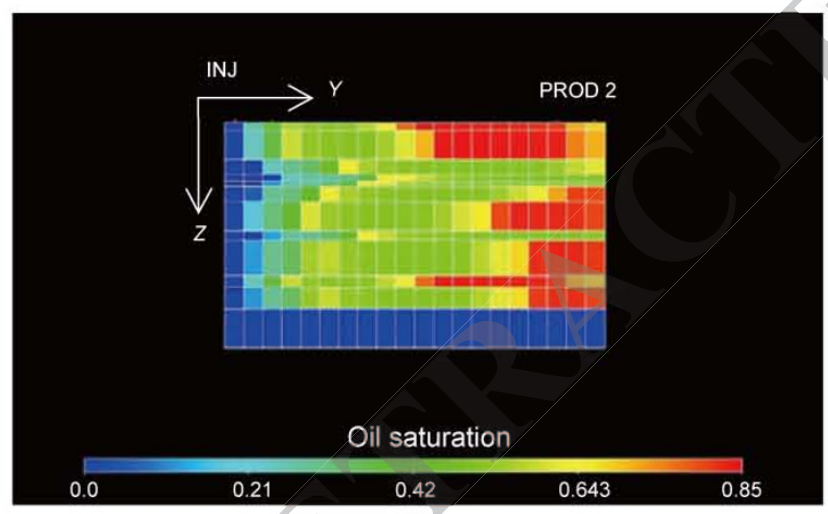

(d) Year \#18

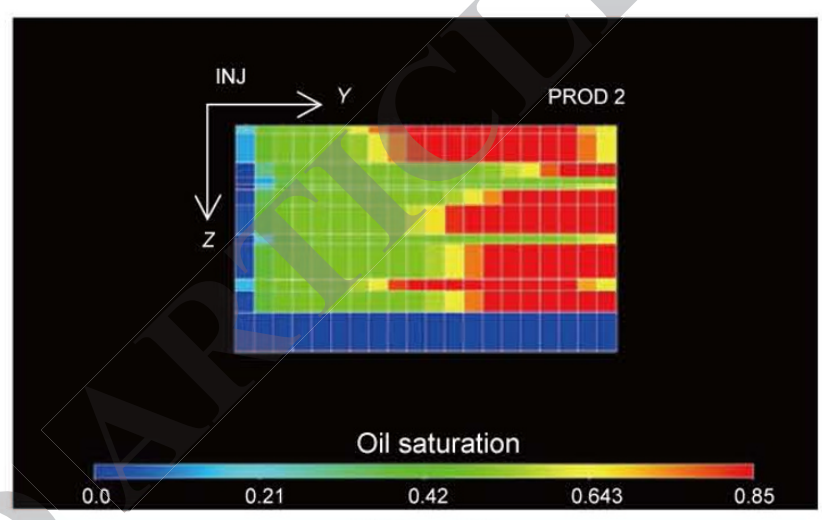

(c) Year \#12

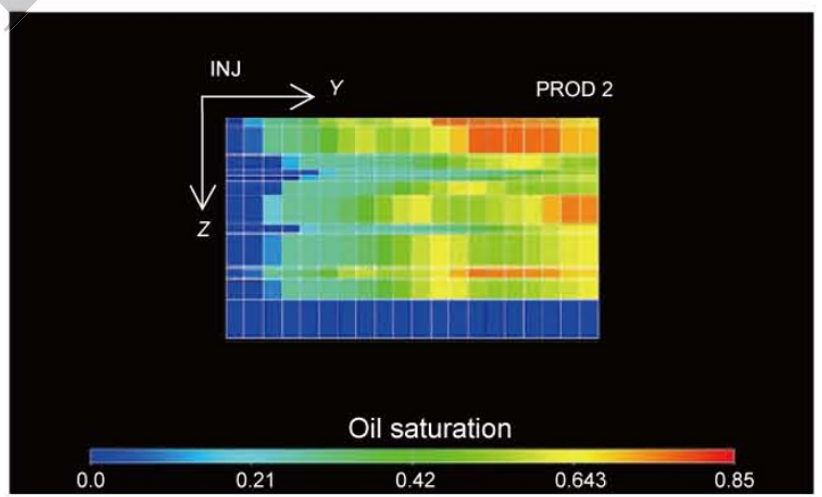

(e) Year \#24

Fig. 6 Cross-sectional view of the oil saturation distribution

Model results show sensitivity to the WAG ratio used. As it is shown in Fig. 8, results indicate that injecting a $100 \% \mathrm{HCPV}$ slug of $\mathrm{CO}_{2}$ with a 1:1 WAG ratio would yield the maximum incremental oil recovery. To reduce the $\mathrm{CO}_{2}$ mobility and delay the breakthrough of the $\mathrm{CO}_{2}$, simulations of polymer injection and blocking agent treatments were performed with a WAG ratio of $1: 1$. Polymer injection reduces $\mathrm{CO}_{2}$ cycling through a high-permeability layer between the injection well and offset production wells. For the polymer injection treatment, the injected water viscosity is increased from 1 to $20 \mathrm{cP}$. The injection pressure is 3,1003,900 psia during the process. Production rates before and after the treatments were compared in Fig. 9. A comparison between the obtained production performance from each pattern is investigated in Fig. 10. Simulation results showed

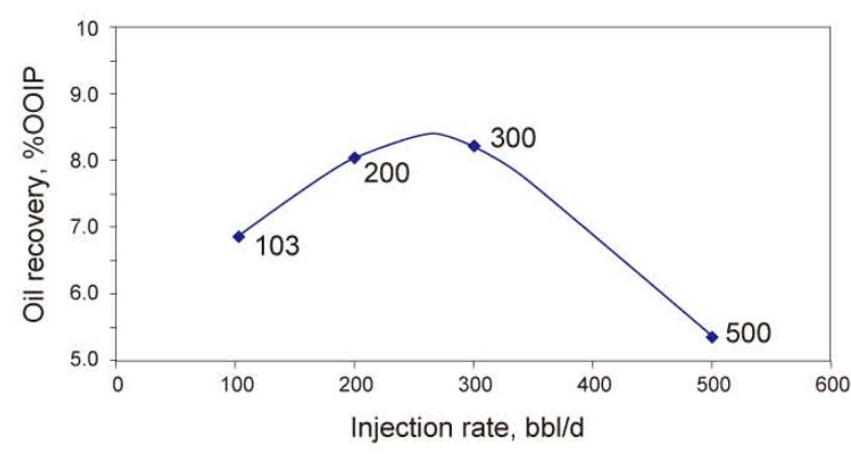

Fig. 7 Oil recovery at a WAG ratio of 1:1 as a function of injection rate 


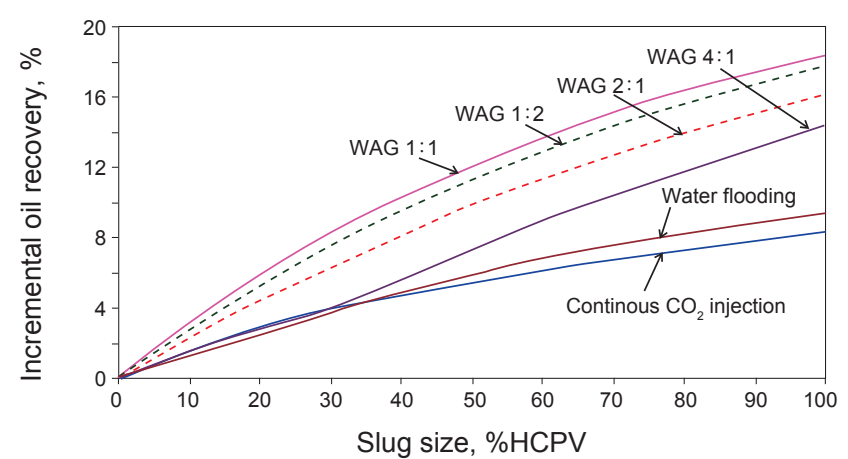

Fig. 8 Comparison of different WAG ratios in terms of the incremental oil recovery as a function of the $\mathrm{CO}_{2}$ slug size

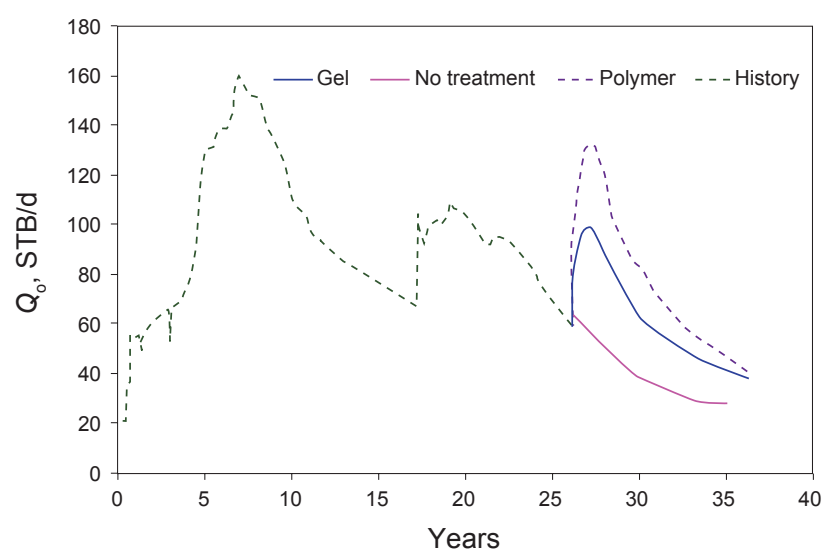

Fig. 9 Comparison of conformance control treatments as a function of oil production rate

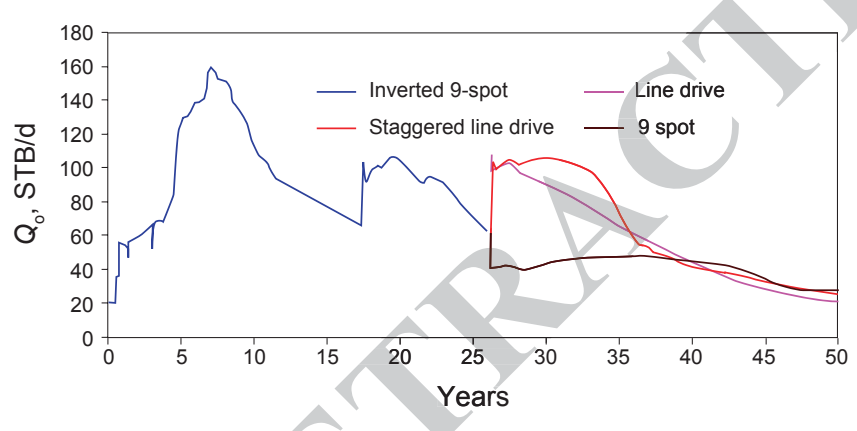

Fig. 10 Comparison of staggered-line-drive, line-drive, and nine-spot well patterns both the staggered-line-drive pattern and the line-drive pattern create an immediate peak above $100 \mathrm{STB} / \mathrm{d}$ in the production rate, which represents approximately a $66 \%$ of increase in production as a result of the pattern reconfiguration.

\section{Conclusions}

Recovery from a WAG process is a function of the injection rate as well as WAG ratio and the $\mathrm{CO}_{2}$ slug size. WAG injection is effective in increasing the sweep efficiency of the injected $\mathrm{CO}_{2}$ in reservoirs. Simulation shows that tertiary $\mathrm{CO}_{2}$ flood would have a maximum recovery of $18 \%$ at a 1:1 WAG ratio and a $\mathrm{CO}_{2}$ slug size of $100 \% \mathrm{HCPV}$. The optimum injection rate for the pattern is $300 \mathrm{RB} / \mathrm{d}$ of $\mathrm{CO}_{2}$ at a WAG 1:1 ratio. The injection of viscous water and polymer results in a positive production response that yields an incremental oil recovery of $32 \%$ and $20 \%$ respectively. Modeling suggests that converting the pattern from the inverted nine-spot pattern to a staggered-line-drive improves the production oil rate by $66 \%$. The $\mathrm{CO}_{2}$ pattern modeling provides guidance for the reservoir management.

\section{References}

Caudle B H and Dyes A B. Improving miscible displacement by gaswater injection. Transactions of AIME. 1959. 213. 281-284

Jarrel P M, Fox C E, Stein M H, et al. Practical aspects of $\mathrm{CO}_{2}$ flooding. Monograph Series. Society of Petroleum Engineers. 2002

Khan S A, Pope G A and Sepehrnoori K. Fluid characterization of threephase $\mathrm{CO}_{2} /$ oil mixtures. Paper SPE/DOE 24130 presented at SPE/ DOE Enhanced Oil Recovery Symposium, 22-24 April 1992, Tulsa, Oklahoma

Lohrenz J, Bray B G and Clark C R. Calculating viscosities of reservoir fluids from their compositions. Journal of Petroleum Technology. 1964. 16(10): 1171-1176

Martin D F and Taber J J. Carbon dioxide flooding. Journal of Petroleum Technology. 1992. 44(4): 396-400

Mathis R L and Sears S O. Effect of $\mathrm{CO}_{2}$ flooding on dolomite reservoir rock. Paper SPE 13132 presented at SPE Annual Technical Conference and Exhibition, 16-19 September 1984, Houston, Texas

Peng D Y and Robinson D B. A new two-constant equation of state. Industrial \& Engineering Chemistry Fundamental. 1976. 15(1): 5964

(Edited by Sun Yanhua) 